SCHWEITZER Gábor

DOI: 10.15170/DIKE.2018.02.01.04

tudományos főmunkatárs

MTA TK JTI

habilitált egyetemi docens

NKE ÁKK

\title{
A Pécsi Ügyvédi Kamara a zsidótörvények korában (1938 - 1944)
}

\section{The Bar Association of Pécs in the Period of Anti-Jewish Laws (1938 - 1944)}

The purpose of the study is to illustrate how anti-Jewish legislation, adopted between 1938 and 1944 in Hungary affected Jewish lanyers or lanyers with Jewish origin in the city of Pécs. Anti-Jewish laws, contrary to the principle of legal equality excluded Jewish lanyers from the management and leadership of Bar Associations and made it almost impossible for Jewish clerks to be a member of the Bar Association. Discriminatory provisions also limited the employment opportunities of Jewish lanyers. During World War II almost two thirds of Jewish lanyers living in Pécs became victims of the Holocaust.

Keywords: Bar Association of Pécs, anti-Jewish laws in Hungary, antisemitism, discrimination, 1938 - 1944

Az alábbiakban azt szeretném bemutatni, hogy miként érintették az 1938 és 1944 közötti időszakban érvényesülő jogkorlátozó, illetve jogfosztó rendelkezések a Pécsett múködő zsidó vallású és zsidó származású ügyvédeket, másként kifejezve, milyen elsődleges következményei voltak a jogállami elvekkel és intézményekkel ellentétes jogalkotói és jogalkalmazói intézkedéseknek. Az áttekintés a Pécsi Ügyvédi Kamara 1938 - 1944 közötti történetére irányuló kutatások első eredményeit kívánja megosztani az olvasókkal. ${ }^{1}$

\section{1.,AA zsidók száma az ügyvédi karban óriási mértékben nő”}

Noha az ügyvédeket is érintő jogkorlátozó illetve jogfosztó rendelkezések törvényi alapjait a társadalmi és a gazdasági élet egyensúlyának hatályosabb biztosításáról szóló 1938. évi XV. tc. (első zsidótörvény), továbbá a zsidók közéleti és gazdasági térfoglalásának korlátozásáról szóló 1939. évi IV. tc. (második zsidótörvény), valamint az ügyvédekre, az ügyvédjelöltekre és az ügyvédi önkormányzatra vonatkozó egyes kérdések szabályozásáról szóló 1941. évi XIII. tc. intézkedései rakták le, már az első zsidótörvény megalkotása előtt felmerült, hogy az ügyvédi kamarák vezetésében illetve az ügyvédi kamarákba felvehető ügyvédek számának megállapításánál figyelembe kell venni a felekezetek, nemzetiségek és fajok országos arányszámát is. Ezt a nagy tiltakozást kiváltó, nem is annyira burkoltan zsidóellenes elképzelést az ügyvédi rendtartásról szóló,

\footnotetext{
${ }^{1}$ A Pécsi Ügyvédi Kamara múltjára (is) vonatkozó szakirodalomhoz lásd KorsósnÉ DELACASSE,_Az ügyvédi kamarák megszületése Magyarországon c. monográfiájának vonatkozó fejezeteit, CsIBI, A Pécsi Ügyvédi Kamara 29-47. valamint VÉRTESI, Ügyvédek Pécs társadalmában 167-194.
} 
Láąár Andor igazságügyi miniszter által 1935-ben készíttetett törvénytervezet tartalmazta. ${ }^{2} \mathrm{Az}$ ügyvédi kamarák akkor erôteljesen tiltakoztak a felekezeti, nemzetiségi és faji kvóta tervezett bevezetése ellen. A Pécsi Ügyvédi Kamara is egységesen foglalt állást a - miként fogalmaztak jogeszmét, az állampolgári jogegyenlőséget valamint az autonómiát legsúlyosabban veszélyeztető törvénytervezettel szemben. ${ }^{3}$ A tiltakozások hatására végül az 1936-ban beterjesztett törvényjavaslatból, miként utóbb az ügyvédi rendtartásról szóló 1937. évi IV. tc.-ből is kimaradt a ,faji paragrafus".

Az előzményekhez ugyanakkor az is hozzátartozik, hogy antiszemita beállítottságú szerzők már évtizedekkel korábban kifogásolták a szabad értelmiségi pályákon - így az ügyvédi karban elhelyezkedő zsidók magas létszámát illetve arányszámát. Ezen szerzők közé tartozott iff. Weszprémy Kálmán, aki 1907-ben megjelent, statisztikai adatokat is felvonultató kötetében hánytorgatta fel a szerinte kizárólag fényes megélhetést biztosító ügyvédi pályán elhelyezkedő zsidók magas

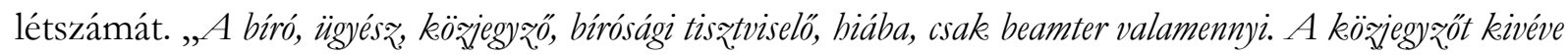
mind csak a fixfizetéséböl nyomorog, a közjegyzóségre meg sok a protekcriós fóka - akarom mondani es₹kimó. Nincs mit csodálni, hogy ezeken a pályákon csodálatosan kevés a zsidó. De van az igazságszolgáltatásnak egy másik ága, aそ, ahol szemesnek áll a világ, abol a jövedelmet csak az korlátozza, hogy egy-egy emberröl csak egy bört lehet lefejteni, mert nincs több (legalább egyszerre, mert apródonként a bör is visszanöés üjra lenyüz̧ató, persze okekal móddal és ügyesen!). Ez a foglalkozási ág az ügyvédi kar, amelynek bihetetlen szaporodásával egy kissé részletesebben kell foglalkoznunk. (...) A zsidók száma az ügyvédi karban óriási mértékben nö. 1890-ben volt a zsidók sұáma 918, 1900-ban 1.538, szaporodott 620-al, azaz. 68.6\%-kal! Akkor, mikor az összes létszám 4.202-röl 4.507-re, 305-el, azaz csak 7.2\%-kal szaporodott! Most azon tünödhetünk, hogy a bírósági ügyforgalom - különösen az apró perek száma - azért nött-e meg olyan nagyon, mert elszaporodott a zsidó ügyvéd, vagy pedig azért szaporodott el a zsidó fiskális, mert megnött az ügyforgalom?

De bizonyos a₹, hogy a zsidó ügyvéd élelmesebb (olyiknak kliens-szállitó vigéczei is vannak) és hogy egy zsidó ügyvéd eltartására több kliens kell, mint egy keresz̨tény ügyvédnek. Már most indokolva látjuk, hogy e drága világban, abol a kliensek rendje napról-napra pusztul és szegényedik: még a megnövekedett ügyforgalom mellett sem él meg a tenger sok. fiskális tisztán a jogkeresö publikumból, mellékfoglalkozásokra van utalva, és a zsidó ügyvéd tényleg visszatér ösei nyomdokára: üzérkedik is. Ismerek ügyvédet, aki utąik, nagyon sok bérrel és gazdálkodik, a legtöbb pedig 'népsegélyzón' betéti srövetkerzeteket alapit."4

A két világháború közötti időszakban a zsidóság károsnak tekintett gazdasági és társadalmi térfoglalását hirdető antiszemita nézetek egyik visszatérô motívuma volt az ügyvédi karban elhelyezkedő zsidók létszámának kiemelése. A zsidó ügyvédek túlzottan magasnak tartott arányszámára Kovács Alajos, a korszak elismert statisztikusa - egy időben a Központi Statisztikai Hivatal elnöke - több művében is hivatkozott. A zsidóság térfoglalásáról szóló 1922-ben megjelent kötetében egyenesen úgy fogalmazott, hogy az utolsó 20-30 év alatt a zsidóság szinte rohammal foglalta el az ügyvédi pályát. „Mig a keresztény ügyvédek száma 20 év alatt csak 12,5\%-kal növekedett, addig a zsidó ügyvédeké 216,9\%-kal, úgy hogy arányszámuk az ügyvédek közt 21,8\%-ról 45,2\%-ra szökött fel."5 Másfél évtizeddel későbbi, „A csonkamagyarországi zsidóság a statisz̧tika tükrében” címú munkájában -

\footnotetext{
2 KovÁCs, Liberalizmus, radikalizmus, antiszemitizmus $127 \mathrm{ff}$.

3 A Pécsi Ügyvédi Kamarának sem kell az új ügyvédi rendtartás. Dunántúl, 1935. szeptember 3. 3.

${ }^{4}$ IFJ. WESZPRÉMY, A magyarországi zsidóságról 81., 83.

${ }^{5}$ KovÁCs, A zsidóság térfoglalása 43.
} 
amelynek statisztikai táblázatai mellesleg az első zsidótörvény indokolásában köszöntek vissza Budapest példáján keresztül arra mutatott rá, hogy jóllehet 1910 óta, az akkori 61,5\%-hoz képest, fokozatosan csökkent a fővárosban a zsidó ügyvédek aránya, az abszolút többséget továbbra is megőrizték. ${ }^{6}$

Az eufemisztikusan a társadalmi és a gazdasági élet egyensúlyának hatályosabb biztositásáról szóló törvényjavaslat ügyvédeket is érintő jogkorlátozásait a miniszteri indokolás az alábbi érveléssel kívánta alátámasztani: „A zsidóság hatalmas gazdasági térfoglalásához természetes következménykeéppen csatlakozott térfoglalásuk az összes értelmiségi pályákon, a sajtóban és az elöadómüvészetekben. A múlt sqáąad utolsó évtizedeinek sqabadelvü politikai, közgazdasági, vámpolitikai, adózási viszonyai között a szociális kötelességekkel meg nem terhelt ipari, kereskedelmi és hiteléleti vállalkozás nagy nyereséget biztositott a gazdasági élet vállalkozóinak. A vagyon viszont biz̨tositotta a magasabb képzettség, a magasabb müveltség megszerzésének lehetöségét, aminek következtében a zsidóság elözönlötte most már a gaz̧dasági pályákon felül a magasabb szellemi képesitéshez kötött szabad kereseti pályákat is, különösen az ügyvédi, az orvosi és a mérnöki pályát. A sajtó és az. elöadómüvészet területének megszállását egyrész̨t a magasabb müveltség megszerzéésének anyagi lehetöségei, másrészt az. magyarázza, hogy a sajtóban és a sqínházban a zsidóság nem utolsó sorban a nyereséges vállalkozás lehetöségét látta és kereste." 7 A zsidóság károsnak tekintett térfoglalását a miniszteri indokolás különféle statisztikai adatokkal is igyekezett alátámasztani: „A₹ ügyvédek között az 1930. évi népszámlálás adatai sұerint római katolikus 1.685, görög katolikus 31, református 774, ágostai evangélikus 233, görög keleti 6, ₹sidó 2.693, egyéb 51. A 2.780 nem zsidó ügyvéddel szemben áll tehát 2.693 zsidó ügyvéd, vagyis az összes ügyvédek 49.2\%-a." Az ügyvédjelöltek körében ugyanakkor 39,4\% volt a zsidók aránya. ${ }^{8}$

A vélelmezett és sérelmezett térfoglalás ellenszerét - azaz a megbomlott gazdasági és társadalmi egyensúly helyreállítását - a jogalkotó az állampolgári jogegyenlőség elvével ellentétes felekezeti illetve faji alapú arányosítás keresztülvitelében vélte megtalálni.

Az 1938. május 29-én kihirdetett 1938. évi XV. tc. rendelkezései ugyanis kimondták, hogy főszabályként öt, kivételesen indokolt esetekben azonban tíz éven belül húsz százalékra kell leszállítani a törvénycikk rendelkezéseinek hatálya alá tartozó zsidók arányát a szabadfoglalkozású pályákon elhelyezkedők - így az ügyvédek, közjegyzők, mérnökök, hírlapírók, színművészek körében, továbbá a tíz főnél többet foglalkoztató pénzügyi, kereskedelmi és ipari vállalkozásoknál. Ezt a kvótát a jogalkotó oly módon kívánta elérni a szabadfoglalkozásúknál - így az ügyvédek esetében is -, hogy a szakmai kamarákba a törvény hatálya alá tartozó zsidó személyeket, a kivételezettektől eltekintve, csak olyan arányban vehetnek fel, hogy számuk a szakmai kamara összes tagjának húsz százalékát ne haladja meg. A törvény intenciói szerint mindaddig, amíg az egyéb, azaz zsidónak nem minősülő kamarai tagok arányszáma az összes tagok számának nyolcvan százalékát nem érte el, zsidót a kamara az újonnan felvett tagok öt százaléka erejéig vehetett csak fel. A numerus clausus - zárt szám - rendszerének visszaállításától várta tehát a jogalkotó a sérelmezett aránytalanságok orvoslását.

Az 1938. évi XV. tc. értelmében ugyanakkor nemcsak az izraelita felekezet tagjai, hanem az 1919. július 31-e után valamely keresztény felekezetre áttértek is zsidónak minősültek. A törvényi rendelkezések végrehajtása céljából a törvényhozás a minisztériumot széles körű rendeletalkotási

\footnotetext{
${ }^{6}$ KOVÁCS, A csonkamagyarországi zsidóság 34.

${ }^{7}$ 616. szám. Törvényjavaslat a társadalmi és a gazdasági élet egyensúlyának hatályosabb biztosításáról, lásd Irományok X 258.

${ }^{8}$ Irományok X 267.
} 
jogkörrel ruházta fel. Az első zsidótörvény összességében mintegy tizenötezer munkavállaló állását veszélyeztette, ami a családtagokkal együtt mintegy ötvenezer embert érintett. ${ }^{9}$

Miután az 1938. évi XV. tc. eredményeit a kormányzat nem tartotta kielégítőnek, a jogalkotó fél esztendővel később hozzáfogott a korábbi rendelkezéseknél kérlelhetetlenebb intézkedések megalkotásához. Az 1939. évi IV. tc. miniszteri indokolása a szabadfoglalkozásúakat - így az ügyvédeket is - érintő szigorúbb rendelkezéseket a következő szempontokkal próbálta alátámasztani. „A társadalmi és a gazdasági élet egyensúlyánake hatályosabb biz̨tositásáról szóló 1938:XV. törvénycikek hatálybalépése óta eltelt fél esztendố tapasztalatai igazolták, hogy ennek a törvénynek, különösen a szabadfoglalkozásúak (ügyvéd, mérnök, orvos, üjságiró) és müvészek (szinmüvészek és filmmüvészele) részére létesült hivatási kamarákban a zsidó tagok felvételére húsz százalékos arányt megállapitó rendelkezései a magyarországi zsidók aránytalan közéleti és gądasági térfoglalásának visszaszoritására, valamint a társadalmi és a gazdasági egyensúly kivánt biztositására nem elegendôk. A megállapitott hüsz százalékos arány ugyanis, figyelemmel arra, hogy a törvény rendelkezése értelmében ez az arány is csak az új felvételek korláto zásával s csak hosszú évtizedek múlva lenne elérhetó, a zsidóságnak a magyarságénál aránytalanul kedvezóbb gazdasági helyzete, vagyonos volta folytán még egy újabb emberöltón át biz̧tositotta volna a zsidóság uralkodó és irányitó szerepét mind az ügyvédi, a mérnöki és az orvosi hivatás, mind a sajtó és a szín-és filmmüvészet terén." 10

Az 1939. május 5-én kihirdetett 1939. évi IV. tc. a korábbi húsz százalékról tizenkét százalékra redukálta az ipari és kereskedelmi vállalatoknál alkalmazható, míg hat százalékra (azaz lényegében országos arányszámára) csökkentette a szabadfoglalkozású pályákon elhelyezkedhető zsidók illetve zsidónak minősülő személyek arányát. Az egyetemekre és főiskolákra felvehető zsidók arányát, a műegyetemre vonatkozó tizenkét százaléktól eltekintve, hat százalékban állapították meg. Teljességgel megvonták a zsidóktól az állami egyedáruság alá eső cikkek árusítását. Erőteljesen korlátozták a zsidók politikai jogait, aminek következtében közel százezren vesztették el országgyúlési és helyhatósági választójogukat. A helyi önkormányzati testületekbe a legtöbb adót fizetők (virilis) közül megválasztott zsidókat megfosztották tagságuktól. Az izraelita felekezet felsőházi képviseletén kívül zsidó nem lehetett a felsőház tagja sem. ${ }^{11}$ Teljességgel elzárták a közszolgálati pályákat a zsidók elől. A rendelkezések nyomán hatvanezren váltak munkanélkülivé, ami a családtagokkal együtt százötvenezer embert jelentett. ${ }^{12}$

A szakmai kamarák - így az ügyvédi kamara - vonatkozásában a második zsidótörvény elrendelte, hogy a kivételezettektől eltekintve zsidó tagként kizárólag olyan arányban vehető fel, hogy a zsidó tagok száma a kamara összes tagjai számának hat százalékát ne haladja meg. Mindaddig tehát, amíg a zsidó kamarai tagok száma a kamara összes tagjai számának hat százalékát kitevő szám alá nem csökkent, zsidót kamarai tagként felvenni nem lehetett. A kamara tisztikarának és választmányának tagja zsidó ugyanakkor csak a tisztikar illetve a választmány tagjai hat százalékának erejéig lehetett. Ha viszont a kamara tisztikarának illetve választmányának tagjai közt a zsidók

\footnotetext{
9 TiLkOvszky, A zsidótörvények 124.

10 702. szám. Törvényjavaslat a zsidók közéleti és gazdasági térfoglalásának korlátozásáról, lásd Irományok XII. 313.

11 Az izraelita felekezet felsőházi képviseletét az 1940. évi XXVII. tc. szüntette meg.

12 TiLkovszky, A zsidótörvények 127. Egykorú kimutatások szerint ugyanakkor 1942. december 31-ig bezárólag 90.000-en vesztették el állásukat, ami az eltartott családtagokkal együtt 220.000 embert jelentett. Idézi DON, A magyarországi zsidóság 154.
} 
aránya meghaladta a hat százalékot, úgy a zsidó tisztségviselők, illetôleg választmányi tagok megbízatása megszűnt, helyüket pedig új választás útján kellett betölteni.

Ez utóbbi rendelkezésnek az értelmezését és végrehajtását volt hivatva előmozdítani a kifejezetten az ügyvédi kamarákra vonatkozó 23.800/1939. I. M. számú rendelet, amely ki is terjesztette a törvényi korlátozások körét. A rendelet értelmében ugyanis megszúnt 1) az ügyvédi kamarák tisztikarának, 2) választmányának, 3) az ügyvédi kamarai helyi bizottságnak, 4) az összeférhetetlenségi bizottságnak, 5) a felvétel tárgyában eljáró bizottságnak, 6) a fegyelmi bizottságnak, 7) az összeférhetetlenségi bizottságnak, 8) a pártfogó ügyvéd kirendelésére hivatott bizottságnak, továbbá 9) az 1937-ben felállított Ügyvédi Kamarák Országos Bizottságába a nem választmányi tagok sorából kiküldött zsidó kamarai tagok mandátuma. A rendelkezések által súlyos csorbát szenvedtek a zsidó vallású vagy származású ügyvédek önkormányzati és érdekképviseleti jogosítványai.

Kizárólag az ügyvédeket, valamint az ügyvédjelölteket érintő további korlátozásokat rögzített az 1941. évi XIII. tc., hiszen egyrészről azt rendelte el, hogy amennyiben egy ügyvédi kamara zsidónak tekintendő tagjainak száma meghaladná a kamara összes tagjainak hat százalékát - az indokolás ezzel összefüggésben rosszallóan hivatkozott arra, hogy öt ügyvédi kamara esetében az 50\%-ot is meghaladta a zsidó ügyvédek aránya - akkor kamarai választási joga csak a választásra jogosult tagok 6\%-ának megfelelő zsidó tagnak lehet, másfelől viszont bizonyos területeken korlátozta ${ }^{13}$ illetve ki is zárta a zsidó ügyvédek közremúködését. ${ }^{14}$

\section{A zsidó vallású ügyvédek müködése mindig elismerésre méltó volt}

De milyen közvetlen hatást váltottak ki a diszkriminatív rendelkezések a Pécsett múködő zsidó ügyvédek körében?

Mielőtt erre a kérdésre válaszolnánk, a Pécsi Ügyvédi Kamaráról és a Pécsett működő ügyvédekről szükséges áttekintést nyújtanunk. A Pécsi Ügyvédi Kamara működési köre 1938-ban - a pécsi és a szekszárdi törvényszékre, valamint a szekszárdi törvényszék bajai kirendeltségére tekintettel - Baranya, Tolna és Bács-Bodrog vármegyére terjedt ki. Az első zsidótörvény megalkotása idején 317 tagja volt a Pécsi Ügyvédi Kamarának, akik közül valamivel több, mint 110 ügyvéd múködött a kamara székelyén, Pécs városában. ${ }^{15}$ Az 1940. évi XVI. tc. a területi illetékesség vonatkozásában jelentős változásokat idézett elő, hiszen a bajai törvényszék felállítása következtében a Bács-Bodrog vármegye területén múködő ügyvédek elkerültek a Pécsi Ügyvédi Kamarától, ami közel 70 fővel csökkentette a Pécsi Ügyvédi Kamara létszámát. ${ }^{16}$ Szerény léptékű növekedést eredményezett ugyanakkor, hogy az egykori Jugoszláviától 1941-ben Magyarországhoz csatolt területek közül a Drávaköz térségében múködő ügyvédeket a Pécsi Ügyvédi Kamarába

\footnotetext{
${ }^{13}$ Az ügyvédi kamara zsidó tagjait bíróság vagy közigazgatási hatóság előtt folyó eljárás során közmegbízatásban csak a megbízatások számának hat százaléka erejéig lehetett részesíteni.

${ }^{14}$ Az Országos Ügyvédi Gyám- és Nyugdíjintézet tisztviselőjévé, igazgatóságának és felügyelő bizottságának tagjává zsidót nem lehetett megválasztani.

15 Összefoglaló nyilvántartás az 1938. június 15-e előtt bejegyzett ügyvédi kamarai tagokról. Pécs, 1938. július 19. MNL BML IX. 603. A Pécsi Ügyvédi Kamara beligazgatási iratai 63. doboz. 1938. évi XV. tc. (zsidótörvény) végrehajtására vonatkozó iratok.

16Állandóan napirenden kell tartani a pécsi igazságügyi palota megépítését. Dunántúl, 1941. május 9. 5.
} 
vették fel. A területi és személyi változások miatt a Pécsi Ügyvédi Kamara 1944. január 1-i névjegyzékében már csupán 222 ügyvéd szerepelt, akik közül 97 ügyvéd múködött Pécsett. ${ }^{17}$

A korabeli pécsi ügyvédtársadalom belső rétegződését, differenciáltságát és jellegzetes alakjait Arató Jenô (1891 - 1979), a Pécsi Királyi Ítélőtábla bírájának szociografikus jellegű, „A polgárember élete tegnap és ma" címú kiadatlan munkája mutatja be. A szerző arra hívta fel a figyelmet, hogy miközben minden ügyvédi irodának önálló élete volt, bizonyos irodatípusok között - noha „, határvonalaik elmosódottak, egymásba olvadók voltake” - mégis különbséget lehetett tenni. ${ }^{18}$ Arató Jenó hatféle iroda- illetve ügyvédtípusról tett említést. Az elsőbe azok a jogtanácsosok, vállalati ügyészek és bankügyészek tartoztak, akik amellett, hogy ellátták vállalatuk jogi képviseletét, saját ügyvédi praxist is folytattak. „Tekintélyes, befolyásos, vagyonos emberek eqek, kiknek nagy sqavuk van a városi közéletben.”19 A következő típushoz „a pénz és kereskedelmi világ ügyeivel” foglalkozó irodák tartoztak. Ifjúkorában maga a szerző is egy ilyen irodában, Krausz Jenô ügyvéd mellett dolgozott ,jogászgyerekként’ ${ }^{20} \mathrm{~A}$ kereskedelmi és pénzvilág ügyeivel foglalkozó ügyvédeket Arató Jenō kivétel nélkül a nagy jövedelmú ügyvédek közé sorolta. ${ }^{21}$ Az ügyvédi irodák harmadik típusát azok az irodák jelentették, amelyeknek ügyfelei „a jómódú polgári világból kerülttek ki”. ${ }^{22}$ Külön irodatípust jelentettek a „paraszt irodáke”, amelyek kliensei szinte kizárólag ,parasztokbóp’ álltak. Ezek az irodák jellemzően a vidéki járási székhelyeken virágoztak. ${ }^{23}$ Az ügyvédi irodák utolsó előtti típusához azok az irodák tartoztak, amelyek a „kisemberek” ügyes-bajos ügyeivel foglalkoztak. ${ }^{24}$ Végül, az ügyvédi irodák hatodik típusát a „politikai beállitottságú irodáke” jelentették, amelyeket legfóképp az jellemzett, hogy az iroda vezetóje - az ügyvédi gyakorlat mellett - országgyúlési képviselőként, vagy városatyaként politikai tevékenységet is folytatott. ${ }^{25}$

Arató Jenô meglátása szerint a pécsi ügyvédek egyik része nagy jövedelemmel illetve vagyonnal rendelkezett, másik része „igen tisz̧tes jövedelemre tett sæ̌ert”, harmadik része viszont szerényebb jövedelemmel volt kénytelen megelégedni - „minden az ügyvéd összeköttetéseitól, eszétöl, agilitásától függö̈t’’ ${ }^{26}$ A vagyon gyűjtését ugyanakkor nem az öncéllal, hanem a szükségességgel hozta összefüggésbe, hiszen az Ügyvédi Nyugdíjintézet csak szerény nyugdíjat fizetett, amiból megélni nem igazán lehetett, így az ügyvédnek önmagának kellett gondoskodnia arról, hogy tartósabb betegsége, munkaképtelensége illetve öregsége idején legyen miből élnie. ${ }^{27}$ Az ügyvédeken általában meg is látszott, hogy nagyobb jövedelemmel rendelkeznek, mint a rögzített fizetéssel rendelkezô

\footnotetext{
${ }^{17}$ A Pécsi Ügyvédi Kamara tagjainak névsora 1944. január hó 1-én. MNL BML IX. 603. b. 80. doboz. Frankó Zoltán, a Pécsi Ügyvédi Kamara titkára 1944. április 6-i elhunytát a neve elé írt † jelezte.

18 ARATÓ, A polgárember élete 28.

19 ARATÓ, A polgárember élete 28.

20 ARATÓ, A polgárember élete 28-29.

21 ARATÓ, A polgárember élete 29.

22 Arató, A polgárember élete 29.

23 ArATó, A polgárember élete 30.

24 ArATÓ, A polgárember élete 30.

25 ARATÓ, A polgárember élete 30.

26 ARATÓ, A polgárember élete 31.

27 ARATÓ, A polgárember élete 31.
} 
tisztviselők, hiszen az ügyvédek „sokkal flottabbul éltek”, sokkal többet engedhettek meg maguknak és a háztartásuk is sokkal bőségesebb volt, mint a tisztviselőké. ${ }^{28}$

Amikor Arató Jenố nevekkel is illusztrálta a különböző típusokat megtestesítő pécsi ügyvédeket, vallási hovatartozásukat természetesen nem nevezte meg. Más források mindenekelőtt a Pécsi Ügyvédi Kamara iratai, a helyi sajtó, valamint a Pécsi Izraelita Hitközség dokumentumai - alapján azonban igen pontosan beazonosíthatók a korszak zsidó ügyvédei. A zsidó vallású ügyvédek közül az Arató Jenő besorolása szerinti kereskedelmi és pénzvilág ügyeivel foglalkozó ügyvédek közé tartozott a zsidótörvényeket megelőző időszakban Greiner Jó́sef, Gombos Ede, Kisfaludi Imre és Kaufer Imre. A jómódú polgári világból kerültek ki ugyanakkor Radnai Emil, Sárkány Armin, Biró Jenô és Büchler Dávid ügyfelei. A kisemberek jogi képviseletét látták el Wolf Mór, Wolf Lajos, Schwarzenberg Andor, Kemény Jenô valamint Molnár Pál irodái. A politikai beállítottságú irodák közé tartozott Balla Ignác ügyvédi irodája, aki a szociáldemokrata párt helyi alapszervezetében töltött be jelentős szerepet. A felsorolás magától értetődően nem törekedett teljességre.

A zsidó vallású pécsi ügyvédek közül a második világháborút megelőzően többeknek volt fontos pozíciója nemcsak az ügyvédtársadalomban, hanem a város és a felekezet közéletében is. Ebbe a körbe tartozott, hogy csak néhány nevet említsünk, Nemes Vilmos (1865 - 1933), aki amellett, hogy hosszú évtizedeken keresztül volt a városi törvényhatósági bizottság tagja, egy ideig a Pécsi Ügyvédi Kamara elnökeként illetve a Pécsi Izraelita Hitközség elnökeként is tevékenykedett. Hosszabb ideig állt ugyanakkor a Pécsi Izraelita Hitközség élén Deutsch Zsigmond (1872 - 1948), ügyvéd és téglagyáros, aki a városi törvényhatósági bizottság tagjaként is múködött. Társadalmi megbecsültségét jelzi, hogy 1940-ig a Pécsi Nemzeti Casino választmányi tagjává is megválasztották. A zsidótörvények vészterhes időszakában, 1940 és 1944 között Greiner Józsefef(1877 - 1944) látta el a Pécsi Izraelita Hitközség, majd a német megszállást követően a pécsi Zsidó Központi Tanács elnöki teendőit.

A zsidó vallású ügyvédek közül többen a legtöbb adót fizetők közül megválasztott tagként kerültek be a városi törvényhatósági bizottságba. Ily módon vált (ismét) városatyává a korszak utolsó helyhatósági választása idején Gombos Ede, Greiner József és Sárkány Ármin.29 Mandátumukat az 1939. évi IV. tc. rendelkezései következtében vesztették el a többi zsidó vallású virilis jogon megválasztott taggal együtt. ${ }^{30}$

A két világháború között a Pécsi Ügyvédi Kamarának két - történetesen zsidó vallású, illetve származású - ügyvédnő tagja is volt: Krausz Sándorné (szül.: Rosenfeld Vilma) és Miskolçyy Vilmosné (szül.: Feldmann Jolán). Mindketten a Pécsi Tudományegyetemen szereztek jogi diplomát és az 1930-as évek első felében Pécsett kezdték meg ügyvédi működésüket. Még időben, hiszen az ügyvédi rendtartásról szóló 1937. évi IV. tc. alapján nők már nem nyerhettek volna felvételt az ügyvédi kamarákba. A sajtó értesülései szerint egyébként Feldmann Jolán volt Pécsett az első, az országban pedig a második „,nöi jogi doktor’. 31

\footnotetext{
28 ARATÓ, A polgárember élete 31. Hasonló jellegű áttekintést nyújt a Pécsett múködő ügyvédekről a Pécsi Napló szerkesztőjének egy részben korábbi időszakra is vonatkozó visszaemlékezése, lásd LENKEI, Negyven év Pécs életéből 101-122.

${ }^{29}$ Megválasztották a városi törvényhatósági bizottság virilisjogú bizottsági tagjait. Pécsi Napló, 1934. december 19. 2.

30 Tizenhét zsidó tagja van Pécs város törvényhatósági bizottságának. Dunántúl. 1939. augusztus 25. 6.

${ }^{31}$ Az első pécsi női ügyvédjelölt kamarai tag lett. Pécsi Napló, 1926. szeptember 17. 5.
} 
Az 1938. évi XV. tc. elfogadását követően az ügyvédi kamarákat adatszolgáltatásra kötelezték a zsidótörvény hatálya alá tartozó kamarai tagok számának és arányának megállapítása érdekében. A Pécsi Ügyvédi Kamara által 1938. július 19-én készített összefoglaló nyilvántartás szerint a Pécs városában múködő 110 ügyvéd közül 47 ügyvéd tekintendő zsidónak, akik közül viszont tízen tartoztak a kivételezettek közé (világháborús tűzharcos illetve világháborúban hősi halált halt szülő gyermeke). ${ }^{32}$ Nem sokkal később a Pécsi Ügyvédi Kamara arról tájékoztatta az Ügyvédi Kamarák Országos Bizottságát - mint az országban múködő ügyvédi kamarák csúcsszervét -, hogy a kamara területén múködő 317 ügyvéd közül 29,45\% az izraeliták aránya. A beadvány melléklete részletezte is az adatokat: 103 ügyvéd tartozott az izraelita felekezethez, 13 ügyvéd ugyanakkor 1919. július 31. után hagyta el az izraelita felekezetet - ők szintén az 1938. évi XV. tc. hatálya alá tartoztak -, míg 24 izraelita ügyvédnek igazolták a tűzharcos mivoltát, aminek köszönhetően mentességet élveztek. A korlátozó rendelkezéseket ily módon 92 izraelita ügyvédre vonatkoztak, ami 29,45\%-nak (valójában 29,02\%) felelt meg. ${ }^{33}$ Ezek az adatok a sajtóban is megjelentek. ${ }^{34}$

Az első zsidótörvény a praxisjogtól ugyan nem fosztotta meg a zsidó ügyvédeket, de ameddig a zsidó ügyvédek aránya az egyes kamarákban nem csökkent $20 \%$ alá, a kamara lényegében nem vehetett fel zsidó ügyvédet tagjai közé. Ez országosan azzal a következménnyel járt, hogy a több száz zsidó ügyvédjelöltből évente mindössze öt-tíz zsidó ügyvédet vettek fel az ügyvédi kamarák tagjai közé.35 A zsidótörvények korában, 1938 és 1944 között Pécsett működő zsidó ügyvédek köre jóformán nem bővült. Ha változott a létszám, akkor az jellemzően a halálozások miatt következett be. A ritka tagfelvételek közé tartozott viszont 1938-ban Kiss László esete, akit mint hadigondozottat - 1938. szeptember 13-án vettek fel a Pécsi Ügyvédi Kamara tagjai közé. A Pécsi Királyi Ügyészség azonban megfellebbezte a kamara döntését, ám az Ügyvédi Kamarák Országos Bizottsága a fellebbezést elutasította. Kiss László édesapja ugyanis a világháborúban és a hadifogságban szerzett súlyos betegsége következtében hősi halottnak minősült, amit a felvételét kérelmező fiatal ügyvéd orvosi igazolásokkal támasztott alá. Ennek következtében Kiss Lásそlót - az 1938. évi XV. tc. 4. \$2. bek a) pontja értelmében - a 20\%-os kvóta megállapítása során nem lehetett a zsidók közé beszámítani, így felvételt nyerhetett a Pécsi Ügyvédi Kamara tagjai közé. ${ }^{36}$

A Pécsi Ügyvédi Kamara 1938. évi jelentése nem hallgatta el az 1938. évi XV. tc. megalkotását illetve következményeit, igaz, a jelentés szövegezői a zsidótörvényben az ügyvédi pálya túlzsúfoltságának csökkentésére irányuló eszközt látták. A jelentés mindazonáltal a körülményekhez képest méltányosan állapította meg (noha a jogkorlátozó illetve jogfosztó rendelkezések ellen a Pécsi Ügyvédi Kamara sem ekkor, sem a későbbiekben nem emelte fel a szavát a nyilvánosság előtt), hogy az 1938. évi XV. tc. nem hárította el a túlzsúfoltság növekedésének a veszélyét, „minthogy a pálya kényszerü elözönlését a nem-zsidó jogásziffúság túlméretezettsége

\footnotetext{
32 Összefoglaló nyilvántartás az 1938. június 15-e előtt bejegyzett ügyvédi kamarai tagokról. Pécs, 1938. július 19. MNL BML IX. 603. A Pécsi Ügyvédi Kamara beligazgatási iratai 63. doboz. 1938. évi XV. tc. (zsidótörvény) végrehajtására vonatkozó iratok.

33 A Pécsi Ügyvédi Kamara 1938. július 29-i kimutatását lásd MNL BML IX. 603. A Pécsi Ügyvédi Kamara beligazgatási iratai 63. doboz. 1938. évi XV. tc. (zsidótörvény) végrehajtására vonatkozó iratok.

3470 és 30\% az arányszám a Pécsi Ügyvédi Kamarában. Dunántúl, 1938. július 30. 4.

${ }^{35}$ KovÁCS, Liberalizmus, radikalizmus, antiszemitizmus 140.

${ }^{36}$ MNL BML IX. 603. A Pécsi Ügyvédi Kamara beligazgatási iratai. 60. doboz. Ügyvédi bejegyzések iránti kérelmek.
} 
is elöidéęi." Ezt az álláspontot tette magáévá az Ügyvédi Kamarák Országos Bizottsága, a királyi ítélőtáblák elnökei, valamint az ügyvédi kamarák többsége is. ${ }^{37}$

Az 1939. évi IV. tc. - miként jeleztük - elsősorban a kamara tisztikarában, választmányában illetve bizottságaiban korlátozta, majd lehetetlenítette el a zsidó ügyvédek részvételét. Elvesztette mandátumát a Pécsi Ügyvédi Kamara elnökhelyettese, Radnai Emil és pénztárosa, Büchler Dávid, a 18 fôs választmány hét tagja valamint két póttagja, továbbá megszűnt a kamara bizottságaiban múködő zsidó tagok és póttagok megbízatása is, ami további 15 zsidó ügyvédet érintett hátrányosan. ${ }^{38} \mathrm{Az}$ irányadó rendelkezések szerint oly módon kellett az új választásokat megtartani, hogy amíg a választmány tagjainak 6\%-a lehetett zsidó, addig a bizottságoknak már egyetlen zsidó tagja sem lehetett.

Némi bizonytalanságot jelentett, vajon elvesztette-e választmányi tagságát Kisfaludi Imre39, aki igazolt tűzharcosként ugyan mentességet élvezett, ám a törvényi rendelkezések értelmében, amennyiben a kamara választmányában a zsidó tagok aránya meghaladja a 6\%-ot, akkor valamennyi zsidó tag mandátuma megszűnik. Miután a Pécsi Ügyvédi Kamara választmánya ezt a dilemmát nem tudta feloldani, „a törvény biteles magyaráąata” érdekében a Budapesti Ügyvédi Kamarán valamint az Ügyvédi Kamarák Országos Bizottságán keresztül az igazságügyi minisztériumhoz fordultak. Az igazságügyi minisztériumtól jóformán postafordultával az a válasz érkezett, hogy az 1939. évi IV. tc. 2. \-ának 1. és 2. bekezdése alá tartozó személyek - az igazolt tűzharcosok is közéjük tartoztak - választmányi és bizottsági tagsága nem szűnik meg. Ennek értelmében tehát Kisfaludi Imre választmányi tagsága és fegyelmi bizottsági tagsága sem szűnt meg.

A kamarát az 1939. évi IV. tc. miatt sújtó személyi változásokat a választmány 1939. május 15-i ülésén jelentették be. Piacsek Zoltán, a Pécsi Ügyvédi Kamara elnöke elismeréssel szólt a jogaiktól megfosztott zsidó ügyvédtársak múködéséről és érdemeiről. A jegyzőkönyv szerint a kamarai elnök „öszinte sajnálkozással' emlékezett meg arról, hogy az 1939. évi IV. tc. életbeléptetése következtében a tisztikar, a választmány valamint a különböző bizottságok zsidónak tekintendő tagjainak és póttagjainak a megbízatása megszűnt, „mert visszagondolva a zsidó vallású tagoknak az elmúlt évtizedekben kifejtett kamarai müködésére, meg kell állapitania, hogy ez. a müködés úgy a qualitás, mint a teljesitett munka mennyisége tekintetében mindenkor elismerésre méltó és kiváló volt és az ügyvédi közzéletet szolgálta”. Külön is méltatta a tisztikar zsidó tagjainak - Radnai Emilnek és Büchler Dávidnak - a múködését. „Legyenek meggyözódve a most kiváló tagok, hogy megbecsülésünk és tiszteletünk kiséri öket és kériük, hogy a kamara érdekeit továbbra is viseljék szívïkön és értékes müködésülkeel ežntúl is támogassanak bennünket." 40 A választmányi ülés végén Radnai Emil köszönte meg a Piacsek Zoltán elismerő szavait, egyúttal arra kérte ügyvédtársait, hogy a tisztségüktől megváló tagokat, akik a törvény tiszteletének gondolatától át vannak hatva és bármilyen mélyen érinti is ôket, meghajolnak a törvény rendelkezései előtt, tartsák meg továbbra is szeretetükben és megbecsülésükben.

\footnotetext{
${ }^{37}$ Kamarai jelentés 19385.

${ }^{38}$ A Pécsi Ügyvédi Kamara választmányának 1939. május 15-i és május 24-i ülésének jegyzőkönyve. MNL BML IX. 603. A Pécsi Ügyvédi Kamara beligazgatási iratai. 64. doboz.

39 Kisfaludi Imre (1897) a második világháborút követően a gazdasági jog témakörében egyetemi magántanári címet szerzett a Pécsi Tudományegyetem Jog- és Államtudományi Karán.

40 A Pécsi Ügyvédi Kamara választmányának 1939. május 15-i ülésének jegyzőkönyve. MNL BML IX. 603. A Pécsi Ügyvédi Kamara beligazgatási iratai. 64. doboz.
} 
A második zsidótörvény következtében megüresedett tisztikari, választmányi és bizottsági helyek betöltésérôl a Pécsi Ügyvédi Kamara 1939. június 3-i „választó közgyülésén” döntöttek. ${ }^{41} \mathrm{~A}$ zsidó ügyvédeknek mindössze arra volt esélyük, hogy a választmány tagjai közé - a kivételezett Kisfaludi Imrén kívül - esetleg beválasztanak egy zsidó ügyvédet is. A bizottsági helyeket ugyanis zsidó ügyvéddel már egyáltalán nem lehetett betölteni. A választás eredményeként Radnai Emil, a korábbi elnökhelyettes a választmányi tagok közé került. Annak nyilvánvalóan semmi realitása sem volt, hogy a tisztújítás során ismételten elfoglalja az elnökhelyettesi pozíciót. Miután a közgyúlésen megjelent 49 ügyvéd közül 19 ügyvédet érintettek a második zsidótörvény rendelkezései, nagy a valószínűsége annak, hogy Radnai Emil választmányi taggá történt megválasztásakor nem-zsidó ügyvédek is rá adták a szavazatukat. A választás következtében a választmány 18 tagja közül ugyan ketten voltak zsidó vallásúak, de a kivételezett Kisfaludi Imre miatt a zsidó választmányi tagok aránya nem haladta meg az 1939. évi IV. tc. által előírt 6\%-ot.

A Pécsi Ügyvédi Kamara választmányának mandátuma 1941-ben járt le. Az őszi tisztújítás alkalmával már egyetlen zsidó vallású ügyvéd sem került be a kamara választmányába ${ }^{42}$, amit nagy valószínűséggel segítettek elő az 1941. évi XIII. tc. rendelkezései is, hiszen - miként fentebb jeleztük - drasztikusan csökkentette a kamarai választójoggal rendelkező zsidó ügyvédek arányát.

Az 1938 és 1941 között elfogadott diszkriminatív törvények nemcsak a kamarai felvétel és a kamarai önkormányzatban való közremúködés tekintetében lehetetlenítették el a zsidó ügyvédeket és ügyvédjelölteket, hanem az elhelyezkedési lehetőségeket és a megbízás-vállalások körét is megszorították. Miközben a további kutatásoknak kell majd részletesebben feltárniuk, hogy milyen konkrét változásokat eredményeztek a pécsi zsidó és nem zsidó ügyvédek körében a jogkorlátozó rendelkezések, bizonyos gazdasági vállalkozások vonatkozásában eléggé egyértelműen kimutatható a zsidó ügyvédek kiszorulása. ${ }^{43}$ A 19. század közepén Hirschfeld Sámuel által alapított Pannónia Sörfőző Rt. 1939 januárjában szüntette meg - nyilvánvalóan az első zsidótörvény hatására - 1.000 pengő végkielégítés kifizetése mellett Greiner József 1932 óta fennálló vállalati ügyvédi megbízatását. ${ }^{44}$ Utóda Visy Imre lett. Hasonló tendencia érvényesült azon vállalkozások esetében is, amelyek igazgatótóságában illetve felügyelő bizottságában zsidó ügyvédek is részt vettek. Az 1939/1940-es esztendőben Stein Alfréd még az Apolló Projektográf Rt. felügyelőbizottsági tagjai között szerepelt, ám a következő esztendőtől kezdve nevével már nem találkozunk a felügyelőbizottsági tagok között. Gombos Ede 1939-ben került ki a Fűszerkereskedők Áruforgalmi Rt. igazgatósági tagjai közül. A Fürst Gyula szállítási és kereskedelmi Rt. (későbbi nevén Szállítmányozási és kereskedelmi rt.) felügyelőbizottsági elnöki tisztét 1939-ig Greiner József, azt követően viszont már Karl Lajos töltötte be. Ennek ellenére maradtak olyan gazdasági- és hitel intézmények is, ahol egészen 1943/1944-ig zsidó ügyvéd látta el a jogi képviseletet. Ebbe a körbe tartozott a Dunántúli Bank Rt., melynek jogi képviseletét Visy Imre és Stein Alfréd látta el.

\footnotetext{
${ }^{41}$ Jegyzőkönyv a Pécsi Ügyvédi Kamara tanácstermében az 1939: 4. tc. 9. \-a és a 23.800/1939 IM sz. rend. értelmében tartott választó közgyúlésről. Pécs, 1939. június 3. MNL BML IX. 603. A Pécsi Ügyvédi Kamara beligazgatási iratai. 63. doboz. 1938. évi XV. tc. (zsidótörvény) végrehajtására vonatkozó iratok.

42 Újból Piacsek Zoltán dr.-t választotta elnökévé a Pécsi Ügyvédi Kamara. Pécsi Napló, 1941. november 26. 2.

43 A személyi változások elsősorban a Magyar Compass/Nagy Magyar Compass korabeli kötetei alapján mutathatók ki.

${ }^{44}$ Harcos, A Pécsi Pannónia Sörgyár története 182.
} 
A további kutatások adhatnak majd részletes választ arra, hogy mennyiben változott a pécsi zsidó ügyvédek ügyfélköre illetve ügyfélforgalma a jogkorlátozó törvények időszakában. A vizsgált korszakban amúgy, miként az azt megelőzőkben is, általános panaszként hivatkoztak az ügyvédi pálya túlzsúfoltságára, a bevételi lehetőségek szúkülésére, továbbá a zugírászattal szembeni hatékony fellépés szükségességére. Mindezek mellett az sem hagyható figyelmen kívül, hogy Magyarország fokozatosan sodródott az újabb világháború felé. A katonaköteles korban lévő nem zsidó ügyvédeket katonai szolgálatra, a zsidó ügyvédeket pedig fegyvertelen kisegítő munkaszolgálatra hívhatták be.

\section{A numerus clausustól a numerus nullusig}

A zsidó ügyvédeket általánosan érintő korlátozó rendelkezések a kormánypárt radikálisait, a nemzeti szocialista illetve hungarista felfogást valló képviselőket, továbbá a szintén szélsőséges nézeteket hirdető Magyar Ügyvédek Nemzeti Szövetségét ${ }^{45}$ nem elégítették ki. A kormánypárti Petró Kálmán már az 1941. évi XIII. tc. képviselőházi tárgyalása során azt indítványozta úgy a maga, mind a pártja nevében, hogy az igazságügyi miniszter „minél hamarabb terjesszen be egy olyan törvényjavaslatot, amely a numerus nullus alapján a zsidó ügyvédek müködését megszünteti."46 A javaslattevő „nemzeti érdeknek”" nevezte, hogy az igazságszolgáltatásban - a bírókhoz és ügyészekhez hasonlóan - kizárólag keresztény ügyvédek működhessenek közre. Miután a vitán felszólaló Radocsay Lásðló igazságügyi miniszter támogatásáról biztosította az indítványt, a képviselőház határozati javaslatot fogadott el arról, hogy „a zsidó ügyvédek térfoglalásának a mai idök szellemében való haladéktalan korlátozása iránt törvényjavaslatot terjesszen be a képviselóház elé." 47 A felsőház azonban elvetette a képviselőház határozati javaslatát, így az ügyvédi numerus nullus ügye egyelőre lekerült a napirendről.48

A zsidó ügyvédek praxisjogtól történő teljes megfosztása 1944. március 19-e után valósult meg. Azt követően, hogy a szövetséges náci Németország csapatai megszállták Magyarországot, az 1944. március 22-én hatalomra kerülő Sžtójay-kormány rendeleti úton folytatta a zsidók gazdasági, társadalmi-, kulturális- és közéletből történő teljes kiszorítását és ezzel párhuzamosan készítette elő és valósította meg - egyelőre a főváros kivételével - zsidók százezreinek gettóba költöztetését, majd halál- és munkatáborokba hurcolását.

Az ügyvédi numerus nullust az 1944. március 29-én kibocsátott, a zsidók közszolgálatának és közmegbízatásának, továbbá ügyvédi működésének megszüntetésére vonatkozó 1210/1944. M. E. rendelet írta elő. A rendelet értelmében zsidót egyrészről nem lehetett felvenni az ügyvédi kamarákba, másrészről pedig az ügyvédi kamarák választmánya 1944. május 31 -ig köteles volt törölni a névjegyzékből - a korábbiakhoz képest is szúkösebben megállapított kivételezettektôl eltekintve - a rendelet hatályba lépése elôtt bejegyzett zsidó ügyvédeket. Az irányadó rendelkezéseknek megfelelően a Pécsi Ügyvédi Kamarának is össze kellett állítania a zsidó ügyvédek

\footnotetext{
45 Működésükhöz lásd KOVÁcs M. Mária hivatkozott monográfiáját.

${ }^{46}$ Napló X 318. (1941. június 27.)

47 Napló X 347-348. (1941. június 30.)

48 237. szám. A felsőház igazságügyi és közjogi bizottságának együttes jelentése az ügyvédekre, ügyvédjelöltekre és az ügyvédi önkormányzatra vonatkozó egyes kérdések szabályozásáról szóló 231. számú törvényjavaslat tárgyában, lásd Irományok V 101. továbbá Napló II 278. (1941. július 18.)
} 
jegyzékét. A Pécsi Ügyvédi Kamara irattárában több - az 1944. január 1-jei állapotokat tükröző nyomtatott tagnévsor is fennmaradt. Az egyik listán gondos kezek „k” betüvel jelölték meg a keresztény ügyvédeket ${ }^{49}$, míg a másik névsoron áthúzták a törölt - azaz zsidó - ügyvédek nevét.50 Az 1944 tavaszán Pécsett múködő 96 ügyvéd közül 50 ügyvéd neve mellé írtak „,k” betűt az egyik listán, míg a másik listán 46 zsidó vallású illetve zsidó származású ügyvéd nevét húzták át. A praxisjogtól megfosztott zsidó ügyvédek irodáiba a keresztény ügyvédek közül irodagondnokokat rendeltek ki. Az irodagondnokok kijelölésekor azonban figyelemmel voltak a zsidó ügyvédek javaslataira is. Legalábbis erre utal az a levél, amelyet a kamarai tagságtól megfosztott zsidó ügyvédek nevében Greiner József intézett a Pécsi Ügyvédi Kamarához, amelyben azt kérelmezte, hogy amennyiben „az alanti zsidó ügyvédeket a Kamara névjegyzékéböl törlik, részü̈kre a megnevezett nem zsidó ügyvédeket kérjük ügygondnokul kijelölni." ${ }_{51} \mathrm{Ez}$ a levél azt valószínúsíti, hogy létezett valamiféle bizalmi viszony és kollegialitás a zsidó és a levélben feltűntetett nem-zsidó ügyvédek között. A Pécsett múködő 46 zsidó ügyvéd közül mindössze ketten nem kívántak javaslatot tenni a nemzsidó irodagondnok személyére nézve. Az irodagondokként felkért keresztény ügyvédek túlnyomó többsége utóbb vállalta a megbízatást, amit a Pécsi Ügyvédi Kamara 1944. május 24-i, a zsidó ügyvédek irodája részére kirendelt irodagondnokok neveit felsoroló hirdetménye is visszaigazolt. ${ }^{52}$ A kamarából törlendő zsidó ügyvédek és a kirendelt irodagondnokok névsorát a napisajtóban is közzétették. A Pécsi Ügyvédi Kamara összesen 81 zsidó ügyvéd és 11 ügyvédjelölt nevét törölte tagjai közül. A 46 pécsi zsidó ügyvéd mellett 9-en múködtek Baranya és 26-an Tolna vármegye területén. ${ }^{53}$ Noha az 1210/1944. M. E. rendelet az ügyvédi kamarák számára az 1944. május 31-i határnapot állapította meg, a Pécsi Ügyvédi Kamara a zsidó ügyvédeket három héttel a kormányzat által megadott határnap előtt zárta ki. Május végén a kamarából kizárt ügyvédek - a Gestapo őrizetében lévőkön és a munkaszolgálaton lévőktől eltekintve - a pécsi zsidók többségével együtt már a gettóban tartózkodtak. Mintegy 2.700 pécsi zsidó polgárt zsúfoltak össze a gettó szűkös területén.

Jó néhány zsidó ügyvédet már a megszállást követő napokban illetve hetekben letartóztattak a náci hatóságok. A Gestapo egyik különítménye 1944. március 21 -én érkezett Pécsre és rögtön megkezdte a tekintélyes zsidók és a megbízhatatlan hírben álló keresztény közéleti személyiségek őrizetbe vételét. Arató Jenő naplófeljegyzései szerint a legelsők között került a Gestapo fogságába a zsidó ügyvédek közül Pap Sándor, Kaufer Imre és Kisfaludi Imre, továbbá jánosi Engel Richárd mérnök, Inselt Jenô magánzó és Boros Miklós, a Hitelbank pécsi fiókjának igazgatója. „A hangulat” kommentálta Arató Jenö a történteket - „nyomott és keserü; mindenki azzal számol, hogy a németek. protektorátust csinálnak az országból; érezzük tehetetlenségünket, gyengeségünket - szidják, átkozzák a

\footnotetext{
49 A Pécsi Ügyvédi Kamara tagjainak névsora 1944. január hó 1-én. A nyomtatvány elején kézírással: „keresztény ügyvédek". A névsor az 1944. április 6-a utáni állapotokat tükrözi, mert az aznap meghalt Frankó Zoltán nevét áthúzták. MNL BML IX. 603. 182. doboz.

${ }^{50}$ A Pécsi Ügyvédi Kamara tagjainak névsora 1944. január hó 1-én. Frankó Zoltán 1944. április 6- i elhunytát a neve elé írt † jelezte. MNL BML IX. 603. b. A Pécsi Ügyvédi Kamara beligazgatási iratai. 80. doboz.

${ }^{51}$ A Greiner József által írt, dátumozás nélküli levélre az érkezés napját jegyezték fel: április 17. MNL BML IX. 603. b. A Pécsi Ügyvédi Kamara beligazgatási iratai. 80. doboz. 1944 I. 45/A. Zsidó ügyvédek törlése.

52 A Pécsi Ügyvédi Kamara 543/1944. (Pécs, 1944. május 24.) hirdetményét lásd MNL BML IX. 603. c. 142. doboz. Kamarai ügyvédek névjegyzékei 1938 - 1945.

${ }^{53}$ Kijelölték a pécsi és baranyai zsidó ügyvédek irodagondnokait. Dunántúl, 1944. május 11. 2.
} 
németeket, de ezen túl nem történik semmi..." 54 A letartóztatások a következő napokban is folytatódtak. Ekkor vették őrizetbe Gombos Ede ügyvédet, Róth Sándor bőrgyári vezérigazgatót és Deutsch Zsigmond téglagyárost, aki korábban ügyvédi praxist is folytatott. ${ }^{55} \mathrm{~A}$ nem-zsidó őrizetesek közé került - Arató Jenô információi szerint - Entz. Béla egyetemi tanár, Külley János városi tanácsnok, Komposcht Szörény, a Magyar Élet Pártjának baranyai főtitkára és Szilas András városi aljegyző is. ${ }^{56} \mathrm{~A}$ Gestapo általi letartóztatások még napokon keresztül folytatódtak. Utóbb őrizetbe vették - mások mellett -Bíró Jenö ügyvédet, Mansfeld Géza orvosprofesszort és Wolf Lajos ügyvédet is. ${ }^{57}$

Wolf Lajost, akit egy feljelentést követően vették őrizetbe a náci hatóságok, előbb a Gestapo helyi központjában, utóbb a városi rendőrkapitányságon kínozták illetve verték meg. Az elszenvedett sérelmek következtében az őrizetbe vétel ideje alatt vérmérgezést kapott és életét vesztette. ${ }^{58}$

A naplóíró Arató Jenó értesülései szerint március végéig mintegy 60 zsidó került a Gestapo fogságába. Majd így folytatta: „A zsidóktól elveszile a rádiót, a telefont, el az irógépeket, fényképeró gépeket stb. Meg lehet állapitani még a legvadabb antiszemiták sincsenek elragadtatva a Gestapo zsidó ellenes akciójától; ą̧tán magyar emberböl biányzilk a kegyetlenkedési hajlam is, hogy örülni tudjon más szenvedésének. Mikor a rádió birfelolvasásai végén felhangzile a szokásos undoritó hangú zsidó ellenes kirobanás, mindenki elcsukja a rádiót, senki sem hallgatja eqt." 59

Április elején tartóztatta le a Gestapo Werner Istvánt, a Pécsi Napló kiadóját, Nemes István „katholizált zsidó ügyvédet” valamint a helyi szociáldemokraták egyik vezetőjét, Balla Ignác „református vallásra áttért zsidó ügyvédet” is. "Ar Arató Jenô keserűen jegyzete meg, hogy „lassankint minden vagyonos vagy kiemelkedöbb zsidó a Gestapo örizetébe kerül. Akadt egy sereg 'magyar' ember, ki mindenféle bajával, fóleg azért, bogy kedves felebarátját beártassa, a Gestapoboz szaladt; ezeket kirúgják azzal, hogy magánügyekkel nem foglalkoznak - a Gestapot csak a zisidók érdeklik..." "61

A letartóztatottak többségét április folyamán elhurcolták Pécsről: „úgy viszilk el őket, hogy még

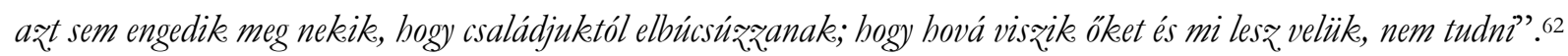
Mint utóbb kiderült a legtöbb zsidó őrizetes a mauthauseni táborba került. ${ }^{63}$

Az auschwitzi deportálást megelőző hetekben a gettóban tartózkodó zsidó ügyvédek folyamatban lévő ügyeit keresztény ügygondnokok látták el. Az irodagondnokok számára azonban - miként ez a következő beadványából ki is derül - szükséges lett volna némi személyes tájékoztatás is a zsidó ügyvédek részérôl. Seffer László ügyvéd, Pfeifer Márk irodájának kirendelt irodagondnoka 1944. június 9-i érkeztetéssel azzal a kéréssel fordult a Pécsi Ügyvédi Kamarához, hogy járjanak

\footnotetext{
54 ARATÓ, Napló 1944. március 21-i bejegyzés

55 ARATÓ, Napló 1944. március 22-i bejegyzés

56 Külley János örizetbe vétele nem tarthatott sokáig, hiszen 1944 júniusában Kolozsvár polgármester-helyettesévé nevezték ki (Dunántúl, 1944. június 25. 6.), ugyanakkor az egyetemre visszakerülő Entz Béla professzornak pedig sikerült megakadályoznia, hogy az orvosi kar nagyértékű műszereit és felszerelését a háború végén a nyilasok nyugatra vigyék, lásd BENKE, 80 éves az orvosi kar 78.

57 ARATÓ, Napló 1944. március 26-i bejegyzés

58 HABEL, Pécsi levelek 319.

59 ARATÓ, Napló 1944. március 26-i bejegyzés

60 Arató, Napló 1944. április 5-i bejegyzés

${ }^{61}$ ARATÓ, Napló 1944. április 5-i bejegyzés

62 ARATÓ, Napló 1944. április 18-i bejegyzés

${ }^{63}$ SCHWEITZER, A pécsi izraelita hitközség története 142.
} 
közre a közigazgatási hatóságoknál, hogy „a névjegyzékbböl törölt ügyvédek a jelenlegi elzárt és szigorúan örzööt helyröl (az úgynevezett gettóból) bizonyos rövid idöre kijöhessenek néba az irodájuk gondnokainak való bövebb felvilágositásuknak a szolgáltatása és adása céljából.” Ezt kívánná meg ugyanis a „keresztény ügyfelek”” érdeke. ${ }^{64} \mathrm{Nem}$ ismeretes, hogy milyen eredményt sikerült Seffer Lászlónak elérnie, annyi azonban valószínúnek látszik, hogy a zsidó ügyvédek - de legalábbis egy részük - nem vesztették el „keresatény ügyfeleikeet’ a diszkriminatív rendelkezések következtében.

A gettó kiürítését követően 1944. július 4-én kezdődött meg a zsidók Pécsről történő elhurcolása. Azután, hogy az auschwitzi megsemmisítő tábor felé tartó teherszerelvények marhavagononként 70-80 halálra szánt zsidóval - elhagyták a pályaudvart, már csak a kivételezett illetve a vegyes házasságban élők maradhattak a városban. Pécs lényegében zsidómentes lett.

A kisegítő katonai munkaszolgálatot teljesítő, továbbá a Gestapo által letartóztatott valamint a haláltáborokba hurcolt pécsi zsidó, vagy zsidó származású ügyvédek közül 30-an váltak a holokauszt áldozatává: Agulár József (1907), Bálint Lászlót (1908), Bedó Antal (1909), Bíró Jenő (1878), Bokor Lász̨ló (1909), Büchler Dávid (1878), Gál Tibor (1910), Greiner József (1877), Gombos Ede (1888), Gyenes Miklós (1902), Hollósi László (1905), Hónig Ferenc (1901), Karczag Jenö (1887), Kemény Jenő (1886), Krausz Sándor† (1895), Krausz. Sándorné (1895), Mandel Károly (1876), Molnár Pál (1893), Nemes István† (1894), Pap Sándor (1884), Pfeifer Márk (1881), Politzer Ferenc (1906), Rasofszky Elek (1888), Schwarczenberg Andor (1896), Stein Alfréd (1900), Steiner Lász̨ló (1907), Steiner Ernö (1891), Tausz Dezső́ (1881), Wolf Lajos (1906), Wolf Mór (1882). ${ }^{65}$

\section{Befejezés helyett}

Az 1938-at követően elfogadott, a polgári jogegyenlőség elvét felrúgó zsidótörvények egyrészről az érintett ügyvédek önkormányzati és érdekképviseleti jogosítványait csorbították, másrészről gyakorlatilag ellehetetlenítették a zsidó ügyvédjelöltek ügyvédi kamarai felvételét, harmadrészt pedig az ügyvédi megbízatások vállalását korlátozták vagy zárták ki. A zsidó ügyvédek praxisjogtól történő teljes megfosztása - azaz a numerus nullus maradéktalan érvényesítése - 1944 tavaszán következett be. Mindezek a folyamatok a Pécsett múködő zsidó ügyvédek sorsának alakulásán keresztül is megfigyelhetôk. Miközben a Pécsi Ügyvédi Kamara 1938-at követően jogkövető magatartást tanúsított - nem emelte fel a szavát a jogkorlátozó rendelkezések ellen -, egy-egy gesztus erejéig még megnyilvánult valamiféle kollegialitás a jogaiktól fokozatosan megfosztott zsidó kamarai tagok irányába. Ez azonban nem változtat azon a tragikus tényen, hogy a pécsi zsidó ügyvédek közül csupán minden harmadik élte túl a második világháború megpróbáltatásait.

\section{Felhasznált források és irodalom}

Magyar Nemzeti Levéltár Baranya Megyei Levéltára (MNL BML) IX. 603. Pécsi Ügyvédi Kamara iratai 1875 - 1944

\footnotetext{
${ }^{64}$ MNL BML IX: 603. b. A Pécsi Ügyvédi Kamara beligazgatási iratai. 80. doboz. 1944 I. 45/A. Zsidó ügyvédek törlése. ${ }^{65}$ A névsor összeállítása az alábbi források, illetve kiadványok alapján történt: Magyar Közlöny, 1945. július 18. 4., 1948. február 25. 2., 1949. január 21. 4., Könnyek könyve 1940 - 1945, továbbá BUCHMÜLLER, A holokauszt során elhunyt magyar ügyvédek 133-134. A zsidó származású, de nem izraelita vallású ügyvédeket † jelöli.
} 
A Pécsi Ügyvédi Kamara 1938. évi jelentése. Pécs 1939 = Kamarai jelentés 1938

Az 1935. évi április hó 27-ére összehívott Országgyúlés Képviselőházának Irományai X. Budapest 1938 = Irományok X

Az 1935. évi április hó 27-ére összehívott Országgyülés Képviselőházának Irományai XII. Budapest 1939 = Irományok XII

Az 1939. június hó 10-ére hirdetett Országgyűlés Felsőházának Irományai V. Budapest 1942 = Irományok V

Az 1939. június hó 10-ére hirdetett Országgyűlés Felsőházának Naplója II. Budapest 1942 = Napló II

Az 1939. június hó 10-ére hirdetett Országgyűlés Képviselőházának Naplója X. Budapest $1941=$ Napló X

Dunántúl, 1935. szeptember 3-i lapszám

Dunántúl, 1938. július 30-i lapszám

Dunántúl. 1939. augusztus 25-i lapszám

Dunántúl, 1941. május 9-i lapszám

Dunántúl, 1944. május 11-i lapszám

Dunántúl, 1944. június 25-i lapszám

Magyar Közlöny, 1945. július 18-i lapszám

Magyar Közlöny 1948. február 25-i lapszám

Magyar Közlöny 1949. január 21-i lapszám

Pécsi Napló, 1926. szeptember 17-i lapszám

Pécsi Napló, 1934. december 19-i lapszám

Pécsi Napló, 1941. november 26-i lapszám

ARATÓ Jenő: A polgárember élete tegnap és ma. Országos Széchenyi Könyvtár Kézirattár, Fond 119.

ARATÓ Jenő: Napló 1941-1946. Országos Széchenyi Könyvtár Kézirattára, Fond 119/3-II.

BENKE József: 80 éves az orvosi kar. 75 éves a pécsi egyetemi képzés. Pécsi Szemle 1998/1-2. 78.

BuCHMÜLLER Péter: A holokauszt során elhunyt magyar ügyvédek. In: KOVÁCS M. Mária (szerk.): Kései főhajtás. A holokauszt jogász áldozatai. Budapest 2016, 133-134.

CsIBI Norbert: A Pécsi Ügyvédi Kamara 1875-1907 között - megalakulás és nehézségek. In: DÉvÉNYI Anna - RAB Virág - SCHWARCZWÖLDER Ádám (szerk.): Hatodik országos interdiszciplináris Grastyán konferencia előadásai. Pécs 2009, 29-47.

DON, Jehuda: A magyarországi zsidóság társadalom- és gazdaságtörténete a 18 - 20. században. Budapest 2006

HABEL János (válogatta és szerkesztette): Pécsi levelek 1944-ből. Dokumentumok a „zsidókérdés” pécsi megoldásáról.

Pécs 2014

Harcos Ottó: A Pécsi Pannónia Sörgyár története. Pécs 1972

KORSÓSNÉ DELACASSE Krisztina: Az ügyvédi kamarák megszületése Magyarországon. Pécs 2012

KovÁCs Alajos: A zsidóság térfoglalása Magyarországon. Budapest 1922

KOVÁCs Alajos: A csonkamagyarországi zsidóság a statisztika tükrében. Budapest 1938

KovÁcs M. Mária: Liberalizmus, radikalizmus, antiszemitizmus. A magyar orvosi, ügyvédi és mérnöki kar politikája 1867 és 1945 között. Budapest 2001

Könnyek könyve. 1940-1945. Mártírjai emlékére a Pécsi Izraelita Hitközség. Pécs 1949

LENKEI Lajos: Negyven év Pécs életéből. Egy pécsi újságíró visszaemlékezései. Pécs 1922

SCHWEITZER József: A pécsi izraelita hitközség története. Budapest 1966

TiLKOvszKY Loránt: „A zsidótörvények mint a Holocaust előzményei”. In: BRAHAM, Randolph L. - PóK Attila (szerk.): The Holocaust in Hungary: Fifty Years Later. New York 1997

VÉRTESI Lázár: Ügyvédek Pécs társadalmában a 19 - 20. század fordulóján. In: VARGHA Lajos - VONYÓ József (szerk.): Tanulmányok Pécs történetéből 10-11-12. Előadások Pécs történetéből ’98, Előadások Pécs történetéből '99 és az Előadások Pécs történetéből 2000 címú konferenciák válogatott előadásai. Pécs 2002, 167-194.

IFJ. WESZPRÉMY Kálmán: A magyarországi zsidóságról I. A magyarországi zsidók statisztikája. Debrecen 1907 